\begin{tabular}{lc}
$\begin{array}{c}\text { Yanbu Journal } \\
\text { of }\end{array}$ & \\
$\begin{array}{l}\text { Engineering } \\
\text { and Science }\end{array}$ & Vol. 8, April $2014(1435 \mathrm{H})$ \\
\hline \hline ISSN: $1658-5321$ & www.yjes.org.sa
\end{tabular}

\title{
PRODUCTION OF VOLATILE FATTY ACIDS (VFA) BY ANAEROBIC DIGESTION OF RICE STRAW/COW DUNG MIX IN BATCH AND FED-BATCH PROCESSES
}

\author{
N. A. Mostafa \\ Faculty of Applied Medical Science, Turaba, Taif University, Saudi Arabia \\ E-mail:dr_eng_hanem@yahoo.com
}

\begin{abstract}
Anaerobic digestion of the mix (4:1) ratio of lime-pretreated rice straw/cow dung was investigated to determine its feasibility as a feedstock to produce volatile fatty acids. Both batch and fed-batch anaerobic digestions were performed. The influence of the solid content and the addition of rumen fiber on the bioreactor performance were studied in batch system. An increase in solid content from 10 to $12 \%$ has increased total acid concentration in liquid product from 10 to $14.69 \mathrm{gL}^{-1}$ and productivity from 2.5 to $3.2 \mathrm{gL}^{-1} \mathrm{~d}^{-1}$. Also, the addition of rumen fiber to rice straw/cow dung has resulted in higher total acid concentration $18.97 \mathrm{gL}^{-1}$ and higher productivity $10 \mathrm{gL}^{-1} \mathrm{~d}^{-1}$. Compared to the batch process at the same solid content of $12 \%$, the fed-batch anaerobic digestion has resulted in higher acid concentration $25 \mathrm{gL}^{-1}$ and higher yield of volatile fatty acids from volatile solids fed from 19 to $32 \%$ as well as higher productivity $4.4 \mathrm{gL}^{-1} \mathrm{~d}^{-1}$. Thus, the present study suggests that the volatile fatty acids' production can be optimized through fed-batch digestion and the addition of rumen fiber to the original feedstock (rice straw/cow dung).
\end{abstract}

Keywords: Anaerobic digestion, cow dung, fed-batch, rice straw, volatile fatty acids (VFA).

\section{INTRODUCTION}

Waste biomass includes resources such as municipal solid waste, sewage sludge, manure and agricultural residues. Currently, these resources are underutilized [1 - 4]. Food waste, fruit-vegetable waste, and dewatered sewage sludge were co-digested in a continuous stirred -tank reactor for biogas production and greenhouse gas reduction [5]. In fact, many of these wastes have a cost associated with their disposal. Also, waste biomass has a negative impact on the environment, such as agricultural residues and manure. Moreover, these wastes are land filled or incinerated which leads to land or air pollution.

Chemicals (e.g. sugars, glycerol, and organic acids) and biofuels might be produced economically from biomass [6 - 9]. By producing chemicals from waste biomass, nonrenewable resources such as petroleum and natural gas can be conserved for later generations. In addition, oxygenated fuels derived from biomass are clean burning and do not add net carbon dioxide to the environment, thereby reducing global warming.

In Egypt, unutilized crop residues are estimated to amount to 5 million tones in 2006. The largest amount of unused crop residues is rice straw (2 million tones). However, significant quantities of cotton stalks and small quantities of other residues may also remain unused [10]. Rice straw as abundant low-cost feed stock was used for the production of cellulose acetate [11], sugars [12], ethanol [13], and methane [14].

For a long time, research has been done to enhance the digestibility of lignocellulosic biomass by focusing mainly on the efficient 
conversion of the hemicellulose to ethanol, methane, and hydrogen. A lot of literatures have been written about the different pretreatment methods that enhance the digestibility of lignocellulosic materials [15]. To increase the organic material solubilization for the organic fraction of the municipal solid waste and to improve the efficiency of anaerobic treatment in the second step, the chemical pretreatment based on lime addition has been studied [16]. Lime pretreatment has been studied also to enhance the digestibility of bagasse/chicken manure [3]. The enzymatic digestibility of lime-treated corn stover was affected by the change of structural features (acetylation, lignification, and crystallization) resulting from the treatment [17]. Dilute acid-pretreatment [18], compressed-hot water [19], and steam pretreatment have been studied [20]. Anaerobic digestion of organic wastes, either for biogas or volatile fatty acid (VFA) production, has been studied. It is an economical and efficient biological technique used for waste disposal as well as for chemicals or biofuels production.

The major research trends in anaerobic digestion, including the analysis of microbial community development, the extension of anaerobic digestion models, the development of pretreatment techniques and upgrading of the produced biogas, have been studied [21]. Also, the feasibility of integrating anaerobic digestion plant with onsite polymeric membrane purification system for conditioned biomethane production has been studied [22]. Moreover, the relationship between microbial activity and microbial community structure in six full-scale anaerobic digesters has been studied [23].

Numerous studies have been focused on the anaerobic digestion of pretreated agricultural residues only [14, 24], animal manure only [1], or agricultural residues co-digested with animal manure [3] to improve $\mathrm{C} / \mathrm{N}$ ratio necessary for anaerobic digestion, thereby increasing the production rate. Other studies have been focused on the biogas or VFA production at large scale, in fed-batch or continuous processes, and with initial high solid content (solid-state fermentation) to increase both production rate and waste disposal capacity. The optimization of biogas production from manure through serial digestion in lab-scale and pilot-scale has been studied [1], in which the VFA production rate has increased from 48 to $70 \%$ with the addition of partially fermented sludge at 10 to $20 \%(\mathrm{v} / \mathrm{v})$ of the total reactor volume [25].

The objectives of this study were to evaluate the effect of: 1 . the initial solid content of the organic waste, 2 . the co-digestion of rice straw/cow dung with rumen fiber, and 3. fedbatch process on the production rate and yield of VFA.

\section{2. MATERIALS AND METHODS}

\subsection{MICROORGANISM:}

The ruminant (e.g. Cow) intestines include a rumen fluid in which large numbers of microorganisms (bacteria, protozoa, and fungi) breakdown cellulose and hemicelluloses, and convert them into volatile fatty acids.

All experiments were conducted with a fresh rumen fluid of cow obtained from the slaughter house, in addition to the different anaerobic microorganisms in soil and black mud which were added as $5 \mathrm{~g}$ solid mass/L.

\subsection{BIOMASS PRETREATMENT:}

Rice straw was collected (local harvest), sun dried and ground to small particles in order to be suitable for pretreatment. Both rice straw and cow dung were lime-pretreated. For good lime dispersion, the biomass was fairly fluid slurry. The lime and liquid loading during pretreatment were $0.05 \mathrm{~g} \mathrm{Ca}(\mathrm{OH}) 2 /$ dry g of biomass and $5 \mathrm{ml}$ liquid/dry $\mathrm{g}$ of biomass. 
The pretreatment condition was $121^{\circ} \mathrm{C}$ (autoclave) for 1 hour. The dried-pretreated biomass was then stored in sealed plastic containers until to be used in anaerobic digestion. The partially digested cellulose and hemicellulose residues associated with the rumen fluid of the slaughtered cow were defined as rumen fiber. The rumen fiber was used as a renewable biomass for anaerobic digestion.

\subsection{BIOREACTOR:}

The experimental set-up used consists of a mechanically-agitated horizontal pilot-scale digester; constructed from stainless-steel with $22 \mathrm{~L}$ total volume and $10 \mathrm{~L}$ working volume as shown in Fig. 1.

The reactor was derived from electric motor and worm-gear reduction unit for mixing the reaction mixture at approximately $60 \mathrm{rpm}$. The agitator was supplied by 21 impellers axially-and-horizontally distributed around the main shaft.

\subsection{BATCH AND FED-BATCH FERMENTATIONS:}

Batch fermentations were initiated under anaerobic conditions by nitrogen gas. The substrate $(10$ or $12 \% \mathrm{w} / \mathrm{v})$, urea $(1 \mathrm{~g} \mathrm{~L}-1)$, $\mathrm{CaCO} 3$ (0.3 g L-1) and inocula were added to the bioreactor. The inhibitor concentration ( $2 \%$ iodoform in ethyl alcohol) was added (120 凶L L-1) daily at the start to inhibit methanogenic bacteria. The $\mathrm{pH}$ was maintained at 7 by the addition of $\mathrm{CaCO} 3$, in all rice straw/cow dung fermentations. For rice straw/cow dung, the two substrates were combined in a 4:1 ratio. While, for rice straw/cow dung co-digested with rumen fibers, the three substrates were combined in a $3: 1: 1$ ratio. All experiments were carried out at mesophilic range $\left(35^{\circ} \mathrm{C}\right)$. Fed-batch fermentation was started after the culture had been established in the digester (ca. 5 days; which is defined as a pseudo-batch period), then about $30 \%$ of the residual solids in the reactors were replaced by fresh substrate (rice straw/cow dung).

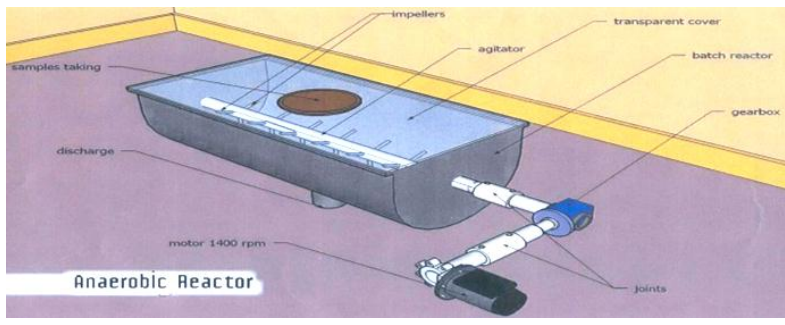

Fig. 1 The Anaerobic Reactor.

Also, one liter of liquid product was removed from the reactor and replaced by a fresh rumen fluid. The fresh substrate took about 3 days to be digested. Therefore, the replacement of solid and liquid was repeated every 3 days with a constant dilution rate $(\mathrm{d}=0.17$ day- 1$)$. Solid and liquid samples were taken periodically for the determinations of volatile solids and volatile fatty acids, respectively.

\subsection{ANALYTICAL METHODS:}

Volatile solids (VS) were determined in the solid residue by drying the samples at $105^{\circ} \mathrm{C}$ for two days, then aching at $550^{\circ} \mathrm{C}$ for two hours. The volatile fatty acids content was determined in the liquid product by steam striping of VFAs, followed by titration [26].

\section{3. RESULTS AND DISCUSSION}

\subsection{BATCH ANAEROBIC DIGESTION (AD) OF RICE} STRAW/COW DUNG AT 10\% SOLID CONTENT:

The results of the rice straw/cow dung during $\mathrm{AD}$ at $10 \%$ solid content are illustrated in Fig. 2. Fig. 3 reveals that the total acid concentration in the liquid product has risen to $10 \mathrm{~g} \mathrm{~L}^{-1}$ with a $2.5 \mathrm{~g} \mathrm{~L}^{-1} \mathrm{~d}^{-1}$ productivity. Also, Fig. 3 shows a sharp increase in volatile solids reduction's percentage to $11.5 \%$ after 15 hours, followed by a slight increase to $13 \%$ after 60 hours, and consistent trend until the end of the batch.

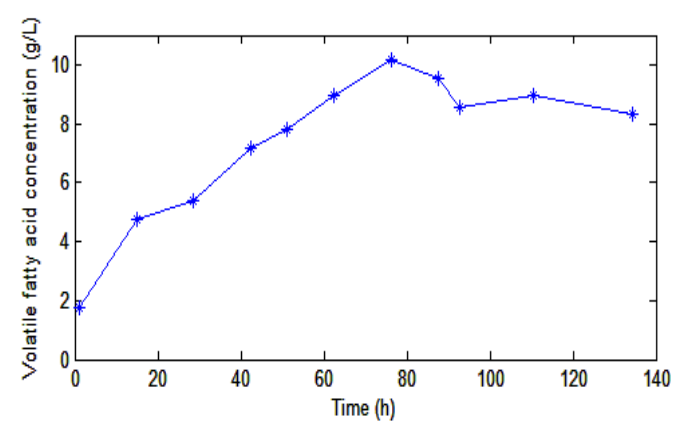

Fig. 2 The time course for volatile fatty acids' production during batch $\mathrm{AD}$ of rice straw/cow dung (10\% solid). 


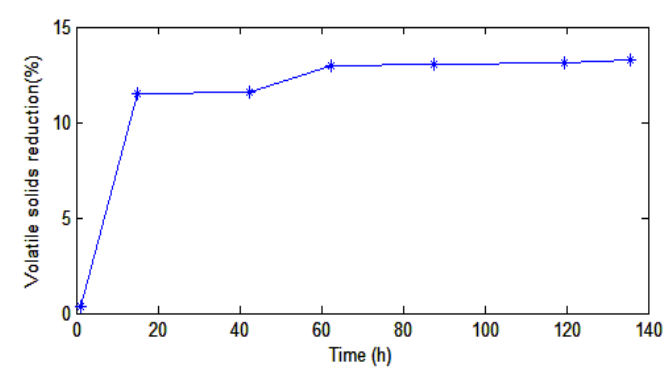

Fig. 3 The time course for volatile solids reduction's percentage during batch $\mathrm{AD}$ of rice straw/cow dung (10\% solid).

\subsection{BATCH ANAEROBIC DIGESTION OF RICE STRAW/COW DUNG AT 12\% SOLID CONTENT:}

Fig. 4 shows a slight increase in the total acid concentration and a maximum acid concentration of $14.69 \mathrm{~g} \mathrm{~L}^{-1}$ after 108 hours with a $3.2 \mathrm{~g} \mathrm{~L}^{-1} \mathrm{~d}^{-1}$ productivity. Fig. 5 reveals that the volatile solids reduction's percentage has a constant increase rate until the end of fermentation period; which indicates a balance between organic waste hydrolysis and acidogenic reaction. Therefore, these results were in agreement with the results shown in Fig. 4.

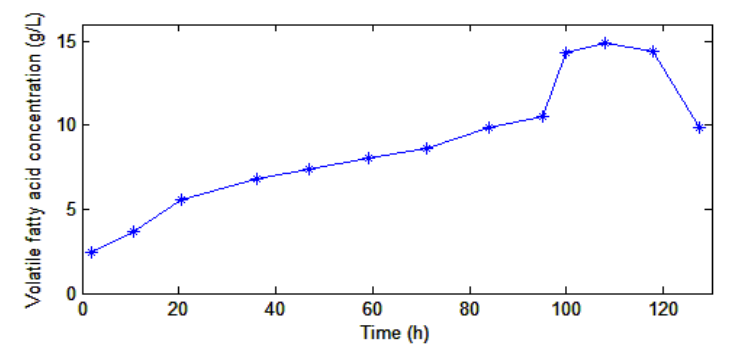

Fig. 4 The time course for volatile fatty acids' production during batch AD of rice straw/cow dung (12\% solid).

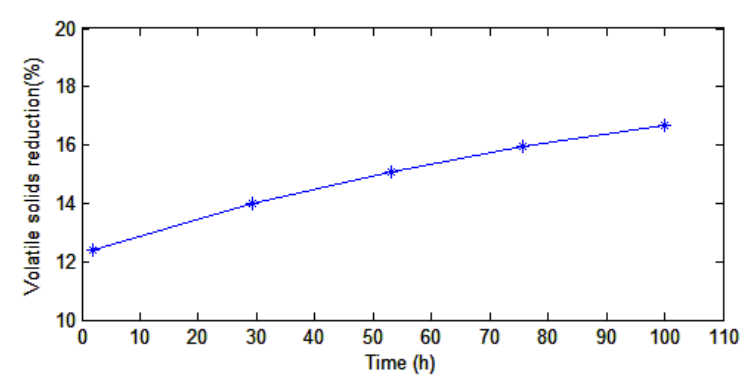

Fig. 5 The time course for volatile solids reduction's percentage during batch $\mathrm{AD}$ of rice straw/cow dung (12\% solid).

\subsection{Batch anaerobic digestion of rice straw/ cow} dung/rumen fiber at $12 \%$ solid content:

Fig. 6 reveals that the total acid concentration in the liquid product has reached to a maximum of $18.97 \mathrm{~g} \mathrm{~L}^{-}$ ${ }^{1}$ after 45 hours with a $10 \mathrm{~g} \mathrm{~L}^{-1} \mathrm{~d}^{-1}$ productivity. Fig. 6 shows also a fall point for VFAs production after 60 hours, followed by a rise until the end of fermentation period. The maximum production point (at 45 hours) could be explained by the rapid digestion of rumen fiber which has resulted in high VFAs concentration after short time, then VFAs producers were inhibited by the high VFAs concentration, and then the produced acid was consumed by the other microorganisms. Also, the final rose in VFAs concentration could be due to the digestion of rice straw.

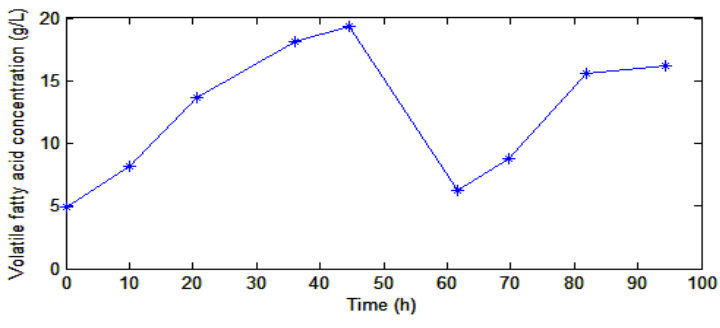

Fig. 6 The time course for volatile fatty acids' production during batch $\mathrm{AD}$ of rice straw/cow dung (12\% solid).

3.4. Fed-batch anaerobic digestion of rice straw/cow dung at $12 \%$ solid content:

Fig. 7 shows that the total acid concentration at the end of pseudo batch period was $14.6 \mathrm{~g} \mathrm{~L}^{-1}$ and has risen to $25 \mathrm{~g} \mathrm{~L}^{-1}$ at quasi-steady state with a $4.4 \mathrm{~g} \mathrm{~L}^{-1} \mathrm{~d}^{-1}$ productivity at a dilution rate of $0.17 \mathrm{~d}^{-1}$. These results could be due to the stabilization and the adaptation of anaerobic culture in the bioreactor. The results illustrated in Fig. 8 reveal that the volatile solids reduction's percentage has reached a maximum point at the end of the pseudo batch period, followed by decrease and increase during the fed-batch period; which indicate the prevalence of the quasi-steady state.

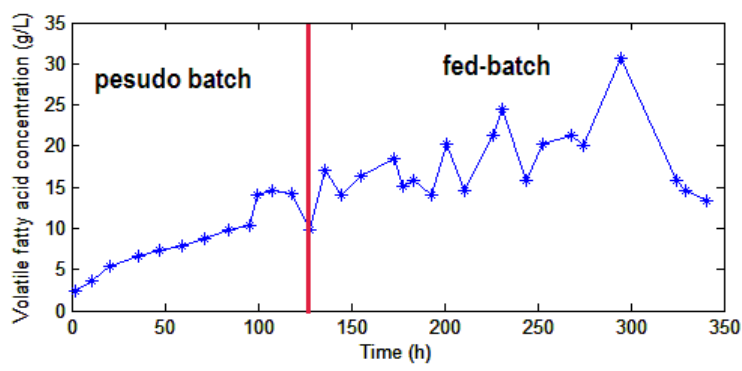

Fig. 7 The time course for volatile fatty acids' production during fed-batch $\mathrm{AD}$ of rice straw/cow dung (12\% solid).

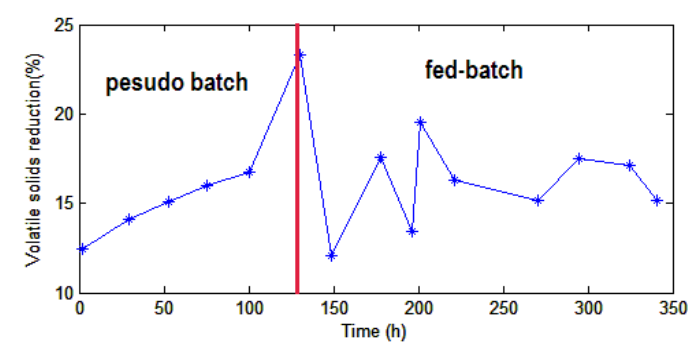

Fig. 8 The time course for volatile solids reduction's percentage during fed-batch $\mathrm{AD}$ of rice straw/cow dung (12\% solid). 


\subsection{THE EFFECT OF AN INCREASE IN SUBSTRATE'S SOLID CONTENT ON ACID PRODUCTION:}

Fig. 9 illustrates the effect of an increase in substrate's solid content from 10 to $12 \%$ on the total acid concentrations in liquid product. Fig. 9 shows that the total acid concentration has increased from 10 to 14.69 g L $\mathrm{L}^{-1}$. Also, Fig. 9 reveals that the productivity has increased from 2.5 to $3.2 \mathrm{~g} \mathrm{~L}^{-1} \mathrm{~d}^{-1}$. These results could be due to the high solid which activates volatile fatty acids' production $[27,28]$. Also, it could be explained by the facts that: 1 . substrate overloading leads to VFAs build-up, and 2. fall in $\mathrm{pH}$ favors the VFAs producers and discourages methane producers.

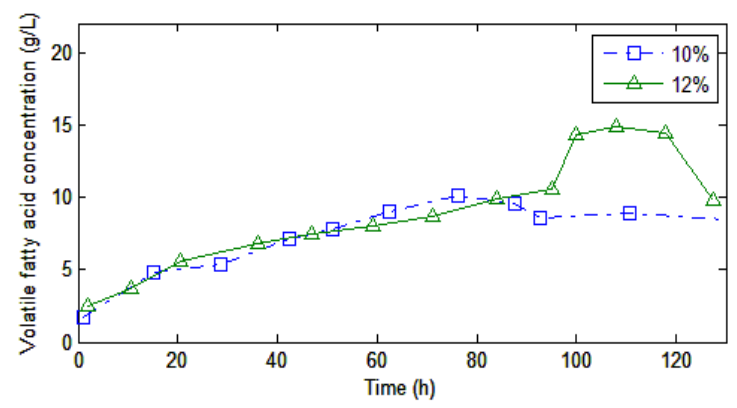

Fig. 9 The effect of an increase in solid content from $10 \%$ to $12 \%$ during batch $\mathrm{AD}$ of rice straw/cow dung.

\subsection{THE EFFECT OF THE ADDITION OF RUMEN FIBER AS A CO-SUBSTRATE ON ACID PRODUCTION:}

Fig. 10 reveals that the addition of rumen fiber as a cosubstrate has increased both total acid concentration from 14.69 to $18.97 \mathrm{~g} \mathrm{~L}^{-1}$ and productivity from 3.2 to $10 \mathrm{~g} \mathrm{~L}^{-1} \mathrm{~d}^{-1}$; about three-fold productivity increase. These results could be due to the good balance in carbon and nitrogen nutrition [28]. Also, it could be due to the partial digestion of rumen fiber by rumen fluid in vivo. Therefore, the rumen fiber became more adapted to be completely digested in vitro and the acidogenic reaction rate became faster compared to the case of native cellulosic waste (e.g. rice straw) alone.

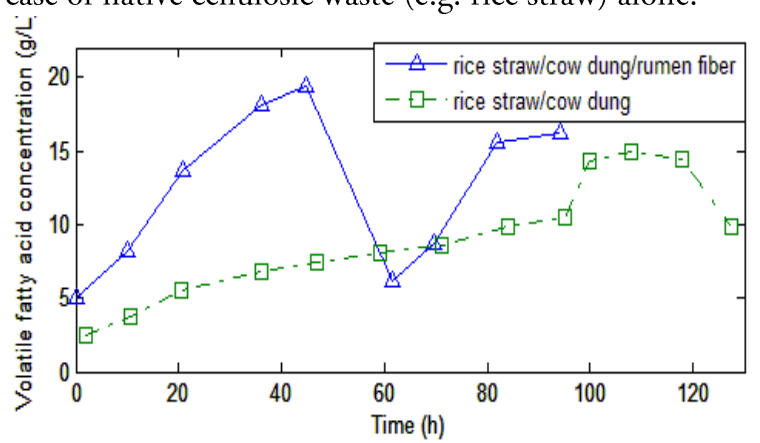

Fig. 10 The effect of a change in substrate type for (rice straw/cow dung), and (rice straw/cow dung/rumen fiber).
TABLE 1. RESULTS SUMMARY FOR BATCH AND FEDBATCH FERMENTATIONS OF RICE STRAW, COW DUNG AND RUMEN FIBER.

\begin{tabular}{|c|c|c|c|c|}
\hline Results & $\begin{array}{l}\text { Batch } \\
10 \% \\
\text { solid } \\
\text { rice } \\
\text { straw/ } \\
\text { cow } \\
\text { dung }\end{array}$ & $\begin{array}{c}\text { Batch } \\
12 \% \text { solid } \\
\text { rice } \\
\text { straw/ } \\
\text { cow dung }\end{array}$ & $\begin{array}{c}\text { Batch } \\
12 \% \text { solid } \\
\text { rice straw/ } \\
\text { cow dung/ } \\
\text { rumen } \\
\text { fiber }\end{array}$ & $\begin{array}{c}\text { Fed- } \\
\text { batch } \\
12 \% \\
\text { solid } \\
\text { rice } \\
\text { straw/ } \\
\text { cow } \\
\text { dung }\end{array}$ \\
\hline $\begin{array}{l}\text { Product acid concentration } \\
\qquad\left(\mathrm{g} \mathrm{L}^{-1}\right)\end{array}$ & 10 & 14.69 & 18.97 & 25 \\
\hline Productivity $\left(\mathrm{g} \mathrm{L}^{-1} \mathrm{~d}^{-1}\right)$ & 2.5 & 3.2 & 10 & 4.41 \\
\hline $\begin{array}{c}\text { Process yield (g total acid/g } \\
\text { total vs. fed) }\end{array}$ & 0.12 & 0.15 & 0.21 & 0.25 \\
\hline $\begin{array}{l}\text { Yield per gram straw } \\
\text { (g total acid/g vs. fed as } \\
\text { straw) }\end{array}$ & 0.15 & 0.19 & 0.26 & 0.32 \\
\hline
\end{tabular}

Table 1 indicates that an increase in substrate concentration from 10 to $12 \%$ has increased both total acid concentration and productivity to about $47 \%$ and $28 \%$, respectively. Also, Table 1 indicates that the addition of rumen fiber has resulted in a $29 \%$ increase in total acid concentration and three-fold productivity. Moreover, Table 1 reveals that the fed-batch process is more economic than batch process because the former has resulted in a $70 \%$ increase in total acid concentration; about $38 \%$ increase in productivity and $68 \%$ increase in the yield of total acid based on straw.

\section{CONCLUSION}

The following conclusions could be made from the present study: 1 . An increase in substrate concentration from 10 to $12 \%$ has increased both total acid concentration and VFAs productivity to about 47 and $28 \%$, respectively. 2 . The use of rumen fiber as a cosubstrate has provided a higher total acid concentration $(18.97 \mathrm{~g} / \mathrm{L})$ at a relatively short fermentation time (2 days) and has resulted in nearly three-fold productivity. 3. The fed-batch process has resulted in higher total acid concentration (25 g/L); about $70 \%$ increase compared to the batch process with the same initial substrate concentration.

The addition of rumen fiber to rice straw/cow dung as a co-substrate is recommended for future work. Also, the increase in substrate solid content and fed-batch anaerobic digestion are recommended for either pollution control as they are utilizing large amount of straw (waste) and have high volatile fatty acids' productivity. Therefore, further research on higher solid content (30\%) and fed-batch anaerobic digestion of the three substrates at different dilution rates are needed to make this process more economically feasible. 


\section{ACKNOWLEDGMENT}

The author wishes to express her gratitude to Prof. Dr. Waheed Yosry Ali, Faculty of Engineering, Mechanical Engineering Deparatment, Taif University, for his valuable and kind assistance.

\section{REFERENCES}

[1] Kaparaju, P., Ellegaard, L. and Angelidaki, I., Optimisation of biogas production from manure through serial digestion: Lab-scale and pilot- scale studies, Bioresource Technology, 100, 701-709, 2009.

[2] Guangqing, L. Zhang, R. Sun, Z. Xiujin, L. and Dong, R., Research progress in anaerobic digestion of high moisture organic solid waste, CIGR Ejournal, IX(13), 1-10,2007.

[3] Mostafa, N. A. Rada, M. A. and Holtzapple, M. T., Production of acetic acid and volatile fatty acids from lime-pretreated bagasse/chicken manure, Alexandria Engineering Journal, 39 (5), 815-826, 2000.

[4] Hartmann H., and Ahring, B., Anaerobic digestion of the organic fraction of municipal solid waste: Influence of co-digestion with manure, Water Research, 39, 1543-1552, 2005.

[5] Xiao, L., Xingbao, G., Wei, W., Lei, Z., Yingiun, $Z$. and Yifei, S., Pilot-scale anaerobic co-digestion of municipal biomass waste: focusing on biogas, Renewable Energy, 44, 463-468, 2012.

[6] Hang, Y. D. and Woodams, E., Enzymatic production of reducing sugars from corn cobs, Lebensm-wiss-u-Technol., 34, 140-142, 2001.

[7] Mostafa, N. A. and Magdy, Y.H., Utilization of molasses and akalona hydrolyzate for continuous glycerol production in a packed-bed bioreactor, Energy Conversion and Management, 39, 671677,1998.

[8] Lopez, A. M., Classen, P.A., Mooibrock, H. and DeVos, W.M., Utilization of saccharides in extruded domestic organic waste by Clostridium acetobutylicum ATCC 824 for acetone, butanol and ethanol, Applied Microbiology Biotechnology, 54(2), 162-167, 2000.

[9] Rejinders, L., Conditions for the sustain-ability of biomass based fuel use, Energy Policy, 34, 863876, 2006.

[10] Whiteman, A., Technical/Policy Note on Agricultural Waste Management in Egypt, Draft Final Report, 2006.
[11] Biswas, A., Saha, B.C., Lawton, J.W., Shogren, R.L. and Willett, J.L. , Process for obtaining cellulose acetate from agricultural by-products, Carbohydrate Polymers, 64, 134-137, 2006.

[12] Karimi, K. , Kheradmandinia, S. , and Taherzadeh, M.J., Conversion of rice straw to sugars by dilute-acid hydrolysis, Biomass and Bioenergy, 30, 247-253,2006.

[13] Karimi, K., Emtiaz, G. and Taherzadeh, M.J., Ethanol production from dilute-acid pretreated rice straw by simultaneous saccharification and ferment-ation with Mucor indicus, Rhizopus oryzae and Saccharomyces cerevisiae, Enzyme and Microbial Technology, 40(1), 138-144, 2006.

[14] Ghosh, A. and Battacharyya, B.C., Biomethanation of white rotted and brown rotted rice straw, Bioprocess and Biosystems Engineering, 20(4), 297-302,1999.

[15] Hendriks, A. and Zeeman, G., Pretreatments to enhance the digestibity of lignocellulosic biomass, Bioresource Technology, 100, 10-18, 2009.

[16] Lopez Torres M., and Espinosa, L., Effect of alkaline pretreatment on anaerobic digestion of solid wastes, Waste Management, 28, 2229-2234, 2008.

[17] Kim, S. and Holtzapple, M.T., Effect of structural features on enzyme digestibility of corn stover, Bioresource Technology, 97, 583-591, 2006.

[18] Sun, Y. and Cheng, J.J., Dilute acid pretreatment of rye straw and bermudagrass for ethanol production, Bioresource Technology, 96, 15991606, 2005.

[19] Chaogang, L. and Wyman, C.E., Partial flow of compressed- hot water through corn stover to enhance hemicellulose sugar recovery and enzymatic digestibility of cellulose, Bioresource Technology, 96, 1978-1985, 2005.

[20] Negro, M. J., Manzanares, P., Oliva, J.M., Ballesteros, I. and Ballesteros, M., Changes in various physical chemical parameters of Pinus pinaster wood after steam explosion pretreatment Biomass Bioenergy, 25, 301-309, 2003.

[21] Lis, A., Joost, L., Jan, D., Live, H., Bart, L., Kris, W., Jan, V., and Raf, D., Anaerobic digestion in global bio-energy production: potential and research challenges, Renewable and sustainable energy reviews, 15, 4295-4301, 2011.

[22] Molino, A., Nanna, F., Ding, Y., Bikson, B. and G. Braccio, Biomethane production by anaerobic 
digestion of organic waste, Fuel, 103, 1003-1009, 2013.

[23] Leticia, R., Partricia, V., Monica, F., Jorge, A., Alfons, J., Juan, M. and Marta, C., Relationship between microbial activity and microbial community structure in six full-scale anaerobic digesters, Microbiological Research, 167(10), 581-589, 2012.

[24] Playne, M. J., Volatile fatty acid production by anaerobic fermentation of lignocellulosic substrates, Advances in Biotechnology, 2, 85-90, 1981.

[25] Banister, S.S. and Pretorius, W.A., Optimization of primary sludge acidogenic fermentation for biological nutrient removal, Water SA, 24 (1), 35-41, 1998.

[26] Warner, A. C., Production of volatile fatty acids in the rumen: methods of measurement, The Commonwealth Bureau of Animal Nutrition [special issue], Nutrition Abstracts and Reviews, 34 (2), 339-351, 1964.

[27] Bulock, J. and Kristiansen, B., Basic Biotechnology, New York: Academic Press, 2nd edition, 1989.

[28] Sosnowki, P., Wieczorek, A. and Ledakowicz, S., Anaerobic co-digestion of sewage sludge and organic fraction of municipal solid wastes, Advances in Environmental Research, 7 (3), 609 $-616,2003$. 


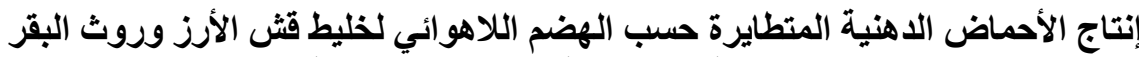 في التغنية ذات الدفعة الواحدة والتمتقطعة التطايط
}

\author{
نجاة عبدالله مصطفى \\ جامعة الطائف، المملكة العربية السعودية
}

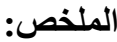

تم دراسة إمكانية إستخدام قش الأرز وروث الأبقار والذى سبق معالجتهم بالجير لإنتاج الأحماض الدهنية المنطايرة، وذللك بالهضم اللاهو ائى لمزيج (4:1) من قش الأرز وروث الأبقار. وقد استخدت كلا من الطريقة المتقطعة و التغذية المتقطعة. تمت دراسة تأثير المحتوى الصلب و إضافة ألياف الكرش على أداء الدفاعل الحيوى الذى يعمل بالطريقة المتقعة. أعطى زيادة في المحتوى الصلب من 10 الى 12\% زيادة في كل من تركيز الحمض الكلى في الناتج السائل (10 إلى 14 جرام/لتز) و وإنتاجية من 2.5 إلى 3.2 جرام/ لتر. يوم أيضاً أعطى إضافة ألياف الكرش إلى قش الأرز / روث البقر أعلى تركيز للحمض الكلى (18.97 جرام/لتر ) و أعلى إنتاجية (10 جرام/ لتر يوم). الهضم اللاهو ائى بطريقة التغذية المتقطعة أعطى أعلى تركيز للأحماض الكلية وهو 25جر ام / لتر ونسبة العائد من الأحماض الدهنية المتطايرة على أساس المو اد الصلبة المنطايرة من 19 إلى 33\% و أعلى إنتاجية (4.4 جرام/ لتر. يوم ) مقارنة مع عملية متقطعة عند نفس المحتوى الصلب (12\%) وتشير الدراسة إلى أنه يمكن أن يكون الإنتاج الأمثل للأحماض الدهنية المنطايرة من خلال الهضم اللاهو ائى بطريقة التغذية المتقطعة وإضافة ألياف الكرش إلى المو اد الأولية الأصلية (فش الأرز / روث البقر). 